\title{
The micro evolution of trade and turnover in Turkey under the global crisis
}

\author{
Alessia Lo Turco*, Daniela Maggioni \\ Università Politecnica delle Marche, Department of Economics and Social Sciences, Piazzale Martelli 8 , \\ 60122 Ancona, Italy
}

\section{A R T I C L E I N F O}

\section{Article history:}

Received 2 August 2012

Received in revised form 3 September 2013

Accepted 20 September 2013

Available online 18 April 2014

\section{JEL classification:}

D22

F10

F14

\section{Keywords:}

Crisis

Exports

Imports

Turnover

furkey

\begin{abstract}
A B S T R A C T
We provide evidence on the effects of the 2009 crisis on Turkish manufacturing. The exploration of firm and firm-product extensive and intensive margins confirms the prevalence of the latter in the fall of export sales and discloses the former's relevance in the dramatic import contraction. The analysis of firm and product heterogeneity reveals that productivity drove the negative evolution of the export intensive margin to such an extent that it significantly affected trade extensive margins and postponable goods were the most affected products. In addition, the foreign demand shock suffered by exporters propagated to their import demand. Interestingly, we show that the crisis hit produced exports less than the carry-along ones and that the domestic market cushioned the downturn effects especially for larger firms. This hints at the importance of domestic counter-cyclical policies.
\end{abstract}

(c) 2014 Elsevier B.V. All rights reserved.

\section{Introduction}

The recent global financial and economic downturn has become one of the main topics in academic debate. The initial financial sector downturn propagated to the real economy and, in particular, the drop in global trade in the first quarter of 2009 was about $30 \%$ on average compared to the previous year (WTO, 2010). The emerging academic consensus is that credit constraints were not the main issue ${ }^{1}$

\footnotetext{
* Corresponding author. Tel.: +39 071 2207250; fax: +39 0712207102.

E-mail addresses: a.loturco@univpm.it (A. Lo Turco), d.maggioni@univpm.it (D. Maggioni).

1 On the contrary, Chor and Manova (2012) find with U.S. data that credit conditions were an important channel through which the crisis affected trade volumes.
} 
(Eaton et al., 2011a; Levchenko et al., 2010; Mora and Powers, 2009) and that the great trade collapse was mostly caused by a demand shock, driven by the evolution of commodity prices and the fall in the demand for postponable goods (Baldwin, 2009).

Among the explanations of the global crisis, the role played by international vertical linkages has received great attention. Firms involved in supply chains should show greater resilience due to the high costs of disrupting long-term relationships (Altomonte and Ottaviano, 2009). At the same time, though, they contributed to the immediate transmission of the downturn in demand from the largest importers (the US, the EU and Japan) to the more peripheral suppliers. International networks of firms may thus have importantly favoured shock propagation across the world. Despite the fact that idiosyncratic shocks at the firm level may importantly determine aggregate dynamics (Gabaix, 2011), only a limited number of studies have dealt with the trade effects of the global recession at firm level.

We thus aim at shedding light on the micro-dynamics that shape the evolution of macro phenomena by providing firm and firm-product level evidence on the crisis impact on trade intensive and extensive margins in the Turkish economy. We especially intend to dissect the role of firm size, efficiency and international exposure in driving the country's response to the recent downturn.

Larger and more productive firms may be less affected by credit restrictions (Greenaway et al., 2007; Muûls, 2008; Manova, 2013) and should be more resilient when facing tougher competition (Melitz and Ottaviano, 2008) and external shocks. At the same time, however, they could be more exposed to the demand slump due to the concentration of their sales in the most severely hit markets (Bricongne et al., 2012) and goods. Exiting the export market may however be rather costly for larger and more efficient firms (Melitz, 2003; Bernard et al., 2003; Arkolakis, 2010; Eaton et al., 2011b) and therefore they might decide to shed only the lowest-competence varieties from their export/product mix and to focus on their core products (Nocke and Yeaple, 2006; Eckel and Neary, 2010; Bernard et al., 2011b; Mayer et al., 2011). A product extensive margin adjustment should therefore be observed. Also, under uncertainty, large firms may contract their orders and nevertheless maintain their sales by making use of their larger inventory (Alessandria et al., 2010). This could be followed by a drop especially in the product level extensive margin, as larger inventories allow for the interruption of several marginal inputs' purchases.

The inspection of firms' international involvement allows us to understand whether international supply chains favoured crisis propagation or, on the contrary, helped to cushion the external shock. We can expect the positive impact of importing on exporting shown in the literature (Muûls and Pisu, 2009; Aristei et al., 2013; Lo Turco and Maggioni, 2013) to be even more important in a crisis: when the export market shrinks, cheaper/higher quality inputs may help to preserve competitiveness in the foreign market. However, an opposite result could emerge if foreign suppliers shut down their operations and domestic firms find no domestic substitutes for the missing imported inputs. Also, the fall in firms' exports may propagate to their imports. By the same token, despite the fact that intragroup financial resources may cushion adverse upcoming credit conditions (Kolasa et al., 2010; Alfaro and Chen, 2012), foreign firms' deep international involvement may above all expose them to the economic downturn originating in foreign markets.

The role that firm size, efficiency and international activity had in shaping the trade effects of the crisis is therefore ambiguous and calls for an empirical investigation. Also, as the crisis hit trade more than domestic sales, the impact of firm and product heterogeneity on the intensive and extensive margins of overall firm turnover is worthy of investigation. We aim to highlight whether the pattern of export sales drove the evolution of overall sales or, on the contrary, in the light of domestic countercyclical fiscal policy interventions (Misch and Seymen, 2012), domestic sales cushioned the adverse effects of the negative international context. Previous evidence has shown that large firms account for a great part of the export collapse, while foreign firms appear to be generally more resilient ${ }^{2}$ (Wagner, 2012; Bricongne et al., 2012; Aisen et al., 2012; Alfaro and Chen, 2012; Kolasa et al., 2010). Compared to this literature we provide some original contributions.

\footnotetext{
${ }^{2}$ On the contrary, Behrens et al. (2012) for Belgium and Godart et al. (2011) for Ireland find no difference between foreign and domestic firms in trade growth and exit rates, respectively.
} 
First, by investigating both the extensive and intensive margins at both firm and firm-product level we deliver a more detailed picture of manufacturing firms' reactions under shock. Our analysis may therefore suggest which tailored policy interventions should be adopted in support of trade and turnover during a crisis. In particular, unveiling the evolution and relevance of the trade extensive margin in the downturn may help to understand whether there is room for policy actions directed to ease the firms' search for new sources or destination markets. Differently from previous evidence, ${ }^{3}$ in the present work we especially test the relevance of firm and product heterogeneity in shaping both firm and firm-product trade extensive margins' response to the crisis and show that neglecting the exploration of the extensive margin would leave out part of the story of the 2009 trade collapse in the Turkish economy.

Second, as our data allow us to distinguish produced and non-produced (Carry Along Trade, CAT) exports (Bernard et al., 2011a, 2012), we explore whether and how the crisis affected the two types of activities. CAT exports generally stem from the activity of "indirect exporters" that may be more exposed to external shocks due to their smaller size and their limited financial and managerial resources. Also, a direct buyer-supplier linkage is missing for CAT products and this could result in looser business relationships, which could be more easily broken when an external shock hits the foreign buyer.

Finally, to the best of our knowledge, this work is one of the few (Paravisini et al., 2011; Aisen et al., 2012) to analyse the response of an emergent economy to the 2009 crisis at the firm level. In our view Turkey is an interesting case since the country was seriously hit by the global recession despite its sustained pre-crisis growth rates and its peripheral position in the international financial system. The sharp decline in GDP ( $-5 \%$ in 2009) was unprecedented with respect to the country's own recent history and to other countries' experience in the 2008-09 global turmoil (Uygur, 2010). Furthermore, the demand drop in the EU meant a significant $24 \%$ export contraction in 2009. In the same way, imports dropped by $27 \%$. The Turkish trade collapse may well reflect a compositional effect due to the predominance of postponable goods in the country's trade pattern. Turkey occupies a growing role within the worldwide supply chains, as witnessed by its increasing weight in world capital and intermediate exports, ${ }^{4}$ and therefore represents a worthwhile setting to analyse the propagation of the real effects of an international crisis and the firm level response.

This work is organised as follows: Section 2 describes the data and some evidence of the crisis impact on the Turkish economy. Section 3 describes our empirical strategy, and Sections 4 and 5 present the results and discuss the findings, respectively. Section 6 concludes.

\section{Data and descriptive statistics}

The sample. Our sample originates from merging the Turkish Annual Industrial Product Statistics (AIPS) with the Structural Business Statistics (SBS) and the Foreign Trade Statistics (FTS) databases. These sources provide information on sales and trade by product and on several firm characteristics for all firms with more than 20 persons employed in the 2005-2009 period. ${ }^{5}$ In particular, we will limit our study on the three-year 2007-2009 subsample, thus comparing firms' 2009 crisis growth rates with the 2008 pre-crisis ones.

In the following sections sold products are defined according to the 10 digit PRODTR classification, while import and export products are defined following the more detailed 12 digit harmonised GTIP

\footnotetext{
${ }^{3}$ The adoption in previous studies of either midpoint growth rates (Aisen et al., 2012; Bricongne et al., 2012) or the number of entering and continuing firms exporting a given variety (Paravisini et al., 2011) makes it difficult to infer how firm and product heterogeneity actually affected trade at the extensive margin. Kolasa et al. (2010) investigated firms' market exit rates, but they left out the firm-product margin and several dimensions of firm heterogeneity as extensive margin determinants. Behrens et al. (2012) on the other hand explore several firm heterogeneity dimensions, but totally omit the analysis of firm and product level extensive margin determinants.

${ }^{4}$ Compared to other emergent and developing economies in the pre-crisis period, Turkey experienced higher capital and intermediate trade growth. In particular, in 2007 the growth of Turkish exports (imports) of capital and intermediate goods was $31 \%$ (21\%) vis-à-vis the $13 \%$ (19\%) export growth recorded in the same goods categories by the remainder of the emerging and developing economies.

${ }^{5}$ The firms in our sample represent more than $75 \%$ of the Turkish manufacturing output and employment, and an even higher fraction of the overall export and import flows of the country.
} 
Table 1

Number of products and overall intensive margin in trade and sales.

\begin{tabular}{|c|c|c|c|c|c|c|}
\hline Year & $Z$ & $J$ & V & $\Delta \% Z$ & $\Delta \% J$ & $\Delta \% V$ \\
\hline \multicolumn{7}{|c|}{ Exports } \\
\hline 2007 & $70,876,137$ & 8822 & 8034 & 14.94 & 1.02 & 13.79 \\
\hline 2008 & $85,062,462$ & 8743 & 9729 & 20.02 & -0.90 & 21.10 \\
\hline 2009 & $74,864,340$ & 8683 & 8622 & -11.99 & -0.69 & -11.30 \\
\hline \multicolumn{7}{|c|}{ Imports } \\
\hline 2007 & $99,909,322$ & 10,202 & 9793 & 9.79 & 0.55 & 9.19 \\
\hline 2008 & $114,280,517$ & 10,162 & 11,246 & 14.38 & -0.39 & 14.83 \\
\hline 2009 & $93,799,635$ & 9876 & 9498 & -17.92 & -2.81 & -15.54 \\
\hline \multicolumn{7}{|l|}{ Sales } \\
\hline 2007 & $302,060,931$ & 3117 & 96,908 & 12.21 & -1.14 & 13.50 \\
\hline 2008 & $332,323,644$ & 3158 & 105,232 & 10.02 & 1.32 & 8.59 \\
\hline 2009 & $308,193,496$ & 3216 & 95,831 & -7.26 & 1.84 & -8.93 \\
\hline
\end{tabular}

Our elaborations are from AIPS, SBS and FTS data. Trade and sales values are in thousands of Turkish liras. $\Delta$ stands for the percentage change of the relevant variable between $t$ and $t-1$.

classification in the descriptive evidence and the more aggregate 6 digit harmonised GTIP classification in the regression analysis. Further details on the databases are available in Appendix A.

The combination of trade and production data allows us to distinguish produced exports - "regular exports" in the remainder - from the bulk of firm exports and thus introduces an important novelty in the analysis of crisis effects. Recent evidence has in fact shown that only a share of a firm's exports corresponds to its own production and only a few firms export their own products only (Bernard et al., 2011a, 2012). Turkish exports present the same pattern (Lo Turco and Maggioni, 2012), and we will show that isolating regular exports from overall exports often delivers different insights on the firm's response to the crisis.

Decomposing trade and sales growth. To describe the contribution of the extensive and intensive margins to the evolution of Turkish aggregate exports, imports and sales before and during the crisis, we start by exploring changes in the number of traded/produced products $(J)$ and the average traded/ produced values by product $(V)$ in the pre-crisis years and in 2009 for all of our variables of interest $(Z)$. Table 1 shows that most of the decline in both trade and turnover was accounted for by the reduction of average values. The drop in the number of imported goods actually played a more significant role only in the case of imports. On the contrary, in the case of sales an increase in the number of sold products is recorded. This simple decomposition already highlights the general intensive margins' predominance in the dynamics of trade and sales and indicates the peculiar relevance of the import extensive margins during the global turmoil.

In order to dig into this evidence, we explore firm-product extensive and intensive margin dynamics in the crisis. Following an analogous decomposition by Goldberg et al. (2010), let $Z_{f p t}$ denote exports (imports or sales, alternatively) for firm $f$ in variety $p$ at time $t$. Firm $f$ belongs to one of the three mutually exclusive groups denoted by $B, D$ and $C$, which represent the set of entering, exiting and continuing exporters/importers/sellers respectively. Then, let $P$ index the set of continuing products, i.e. those that the firm trades/sells both in $t$ and $t-1$, and $E$ the set of entering or exiting products, i.e. those traded/sold only in $t$ or $t-1$. Now, further decomposing set $E$ in the set of product additions, $A$, and droppings, $D$, and splitting set $P$ into the sets of growing, $G$, and shrinking, $S$, products, the overall relative change of our outcome of interest in the economy can be defined as:

$$
\Delta Z_{t}=\sum_{i \in B} \Delta Z_{f t}+\sum_{f \in D} \Delta Z_{f t}+\sum_{f \in C}\left(\sum_{p \in A} \Delta Z_{f p t}+\sum_{p \in D} \Delta Z_{f p t}+\sum_{p \in G} \Delta Z_{f p t}+\sum_{p \in S} \Delta Z_{f p t}\right)
$$

As is the standard in trade literature, a variety $p$ indexes a specific product-market combination. Table 2 displays such decomposition for the growth of overall, capital, intermediate and final goods 
Table 2

Decomposition of firm trade growth.

\begin{tabular}{|c|c|c|c|c|c|c|c|c|c|c|}
\hline \multirow[t]{2}{*}{ Year } & \multirow{2}{*}{$\begin{array}{l}\Delta \% \\
\text { Total }\end{array}$} & \multicolumn{3}{|c|}{$\Delta \%$ Extensive - Firm } & \multicolumn{3}{|c|}{$\begin{array}{l}\Delta \% \text { Continuing Firms } \Delta \% \text { Exten- } \\
\text { sive - Variety }\end{array}$} & \multicolumn{3}{|c|}{$\Delta \%$ Intensive - Variety } \\
\hline & & Net & Entry & Exit & Net & Additions & Droppings & Net & Growing & Shrinking \\
\hline \multicolumn{11}{|c|}{ Exports } \\
\hline & \multicolumn{10}{|l|}{ All Goods } \\
\hline 2007 & 1494 & 0.14 & 1.16 & -1.02 & 5.41 & 1700 & -11.59 & 9.39 & 29.42 & -20.02 \\
\hline 2008 & 20.02 & -0.41 & 1.09 & -1.50 & 7.64 & 18.63 & -10.99 & 12.79 & 32.62 & -19.84 \\
\hline \multirow[t]{2}{*}{2009} & -11.99 & -0.04 & 1.09 & -1.13 & 0.41 & 14.54 & -14.13 & -12.35 & 20.62 & -32.97 \\
\hline & \multicolumn{10}{|c|}{ Capital Goods } \\
\hline 2007 & 29.78 & 1.90 & 3.87 & -1.97 & 7.01 & 21.47 & -14.45 & 20.87 & 32.85 & -11.97 \\
\hline 2008 & 23.59 & 0.25 & 2.22 & -1.97 & 8.61 & 22.05 & -13.44 & 14.73 & 29.14 & -14.41 \\
\hline \multirow[t]{2}{*}{2009} & -25.40 & -0.88 & 2.20 & -3.08 & -1.51 & 14.57 & -16.08 & -23.01 & 12.25 & -35.26 \\
\hline & \multicolumn{10}{|c|}{ Final Goods } \\
\hline 2007 & 8.00 & -0.23 & 1.48 & -1.71 & 3.02 & 11.13 & -8.11 & 5.20 & 27.36 & -22.16 \\
\hline 2008 & 7.06 & -0.34 & 1.35 & -1.69 & 3.46 & 11.14 & -7.69 & 3.95 & 27.46 & -23.51 \\
\hline \multirow[t]{2}{*}{2009} & 3.78 & 0.70 & 2.15 & -1.45 & 4.53 & 12.78 & -8.25 & -1.45 & 27.55 & -29.01 \\
\hline & \multicolumn{10}{|c|}{ Intermediates } \\
\hline 2007 & 15.97 & 0.20 & 1.09 & -0.88 & 6.59 & 19.61 & -13.02 & 9.17 & 30.02 & -20.85 \\
\hline 2008 & 29.38 & -0.40 & 1.24 & -1.63 & 10.39 & 22.74 & -12.35 & 19.39 & 38.26 & -18.87 \\
\hline 2009 & -17.83 & -0.32 & 0.58 & -0.90 & -1.63 & 15.12 & -16.75 & -15.87 & 18.97 & -34.85 \\
\hline \multicolumn{11}{|c|}{ Imports } \\
\hline & \multicolumn{10}{|l|}{ All Goods } \\
\hline 2007 & 9.79 & 0.35 & 0.79 & -0.44 & 3.27 & 18.86 & -15.59 & 6.17 & 28.14 & -21.96 \\
\hline 2008 & 14.38 & 0.00 & 0.53 & -0.53 & 2.29 & 16.61 & -14.32 & 12.10 & 32.14 & -20.04 \\
\hline \multirow[t]{2}{*}{2009} & -17.92 & -0.85 & 0.18 & -1.03 & -2.09 & 14.51 & -16.60 & -14.98 & 17.50 & -32.47 \\
\hline & \multicolumn{10}{|c|}{ Capital Goods } \\
\hline 2007 & 1.37 & 0.83 & 3.60 & -2.78 & 1.57 & 32.38 & -30.82 & -1.03 & 23.21 & -24.23 \\
\hline 2008 & 0.33 & 1.01 & 3.54 & -2.53 & -3.10 & 28.36 & -31.46 & 2.42 & 24.96 & -22.54 \\
\hline \multirow[t]{2}{*}{2009} & -14.97 & -1.28 & 2.02 & -3.30 & -6.70 & 24.31 & -31.01 & -6.99 & 19.81 & -26.80 \\
\hline & \multicolumn{10}{|c|}{ Final Goods } \\
\hline 2007 & -2.09 & 0.61 & 1.39 & -0.79 & 4.52 & 13.43 & -8.92 & -7.22 & 16.80 & -24.01 \\
\hline 2008 & 14.04 & -0.07 & 1.26 & -1.33 & 2.52 & 12.90 & -10.38 & 11.59 & 29.99 & -18.40 \\
\hline \multirow[t]{2}{*}{2009} & 8.90 & -0.94 & 0.75 & -1.69 & 6.69 & 15.58 & -8.89 & 3.15 & 25.28 & -22.13 \\
\hline & \multicolumn{10}{|c|}{ Intermediates } \\
\hline 2007 & 12.30 & 0.31 & 0.75 & -0.43 & 3.50 & 16.74 & -13.24 & 8.49 & 29.91 & -21.43 \\
\hline 2008 & 16.46 & -0.21 & 0.33 & -0.55 & 3.13 & 14.66 & -11.53 & 13.54 & 33.49 & -19.94 \\
\hline 2009 & -20.95 & -0.91 & 0.17 & -1.08 & -2.17 & 12.76 & -14.93 & -17.87 & 16.47 & -34.35 \\
\hline \multicolumn{11}{|l|}{ Sales } \\
\hline & \multicolumn{10}{|l|}{ All Goods } \\
\hline 2007 & 11.90 & - & - & - & 0.68 & 5.73 & -5.05 & 11.22 & 18.83 & -7.61 \\
\hline 2008 & 10.41 & - & - & - & 0.62 & 3.69 & -3.07 & 9.79 & 18.76 & -8.97 \\
\hline 2009 & -7.61 & - & - & - & 0.72 & 3.07 & -2.35 & -8.33 & 10.67 & -19.00 \\
\hline
\end{tabular}

Our elaborations from AIPS, SBS and FTS data. This decomposition follows from Eq (1). Data on births and deaths of firms are not available, as a consequence the firm extensive margins are missing.

exports and imports ${ }^{6}$ and for nominal sales growth. However, regarding sales, we are not able to take firm entry/exit into account since we cannot be sure that exit and entry dynamics in the database actually reveal true firm births and deaths. ${ }^{7}$ Thus, focusing on continuing firms, the decomposition corresponds to the third term of Eq. (1), where variety $p$ in this case just indexes a sold product. The

\footnotetext{
${ }^{6}$ We define as intermediates those products belonging to the Broad Economic Category (BEC) codes 111, 121, 21, 22, 31, 322, 42, 53. Capital goods are products included in the BEC codes 41 and 521. The remaining codes denote final goods. It is worth noting that according to this split, the so-called postponable goods may fall under both the intermediate and capital good categories.

${ }^{7}$ In the AIPS a firm's exit from the database could stem from a change in the firm sector of activity or a decline in the number of employed persons that determine a firm's exit from the sampling threshold.
} 
table shows that the intensive margin contribution in the evolution of trade and sales increased during the recession and, in particular, was solely responsible for the overall exports contraction in 2009 (Behrens et al., 2012; Bricongne et al., 2012; Aisen et al., 2012; Barba Navaretti et al., 2011; Wagner, 2012). Different evidence is unveiled instead for the positive evolution of final goods exports and imports and the contraction of capital goods imports that were importantly driven by the entry/exit of firms from foreign markets and by the adding/dropping of some traded varieties. The table also delivers another general feature of the extensive margin of trade: within a firm, product churning is more pronounced than the firm entry and exit process, but its role is greatly reduced during the crisis. An exception is represented by imports of capital goods, for which product droppings gained importance during the crisis (Baldwin, 2009; Levchenko et al., 2010; Kolasa et al., 2010).

Exploring the role of firm heterogeneity. To understand if firm and product heterogeneity played a different role during the recession compared to the pre-crisis period, we compute the changes of each intensive margin between 2009 and 2008 and adopt the Kolmogorov-Smirnov test of equality of their distributions among firm and product groups. ${ }^{8}$ In the present work, extensive margins are defined as the firm export/import entry and exit rates and the probability to stop exporting/importing/selling a good at firm-product level. Intensive margins are instead measured as the annual growth of firm and firm-product exports/imports/sales. Here we focus on the intensive margins only, as the computation of any extensive margin change over time lacks any kind of meaning.

Table B2 shows that exporters experienced a significantly larger contraction between 2008 and 2009 in both firm and firm-product sales growth compared to non-exporters, and the same is true for non-importers, domestic owned and small sized firms when compared to importers, foreign owned and large firms, respectively. Also, firm trade growth between 2008 and 2009 contracted significantly more for larger, more productive firms, importers and foreign firms. The latter, however, went through a lower contraction of import growth between 2008 and 2009 with respect to domestic firms. This evidence hints at a relevant role of firm and product heterogeneity in the crisis, but it does not allow us to identify the impact of each firm and product characteristic, ceteris paribus Regression analysis may be more suitable for this aim and presents a larger scope of implementation, as it permits to explore the significance of firm and product heterogeneity in the evolution of the extensive margins as well. In the remainder of the work our empirical strategy will thus rest on regression model estimates.

\section{Empirical strategy}

To assess the impact of the crisis at the micro level, we follow a straightforward approach and explore the above defined extensive and intensive margins at firm and firm-product level for exports, imports and sales. We then regress each margin on a bunch of firm characteristics in the previous year, on a dummy indicator for the crisis and on their interaction in order to assess the overall effect of the crisis and to test whether and to what extent the crisis had a heterogeneous impact on the economic performance of different types of firms and goods. In this respect, our approach is very close to that adopted by Behrens et al. (2012) and consists of a sort of difference-in-differences analysis where the crisis is the treatment dummy whose interaction with firm and product characteristics allows for the dissection of the differential treatment effect for some groups of observations vis-à-vis the experience of the counterfactual groups. As a consequence, we do not include firm fixed effects in the empirical models below, as this would cause a loss of identification of the role of firm heteroeneity in the crisis. Then, by simple OLS, ${ }^{9}$ we estimate the two following models for the firm and firm-product margins,

\footnotetext{
${ }^{8}$ A detailed definition of the margins is included in the upper panel of Table B1 in Appendix B.

${ }^{9}$ For the extensive margins we chose to estimate a linear probability model instead of a probit model, since the former allows for the inclusion of several dummy variables and their respective interactions. The STATA command inteff that calculates the interaction effect and the corresponding standard error and z-statistic in logit and probit models has a very long computation time and only treats one interaction at a time. Having more than one interaction and our computation time being constrained, we prefer to tackle our empirical model by means of the more flexible linear probability model. However, the adoption of probit models for the restricted model without the interaction terms delivers the same insights and the relative results are available upon request.
} 
respectively:

$$
\begin{aligned}
q_{f t}=\alpha & +\beta_{0} \text { Crisis }+\beta_{1}^{\prime} W_{f t-1} * \text { Crisis }+\gamma^{\prime} W_{f t-1}+\epsilon_{f t} \\
q_{f p t}= & \alpha+\beta_{0} \text { Crisis }+\beta^{\prime}{ }_{1} W_{f t-1} * \text { Crisis }+\gamma^{\prime} W_{f t-1}+\beta^{\prime}{ }_{2} X_{f p t-1} * \text { Crisis }+\phi^{\prime} X_{f p t-1}+\delta_{p} \\
& +\epsilon_{f p t}
\end{aligned}
$$

In the above equation, $q_{f t}$ measures firm extensive or intensive margins for firm $i$ in year $t$, while $q_{f p t}$ denotes the firm-product margins for firm $f$ and product $p^{10}$ in year $t$, with $t=2008,2009$, as described above. Crisis is the crisis dummy taking the value 1 in 2009 and zero otherwise, and $W$ in both models is a vector of one-year lagged firm characteristics ${ }^{11}$ which also includes a full set of two-digit sector dummies. The lower panel of Table B1 in Appendix B describes our right-hand side variables, which are the firm's size, productivity, export and import status and foreign ownership. Table B3 in the Appendix displays the summary descriptive statistics for our regressors. In the estimation of the firmproduct margins, $X$ includes two dummies identifying the economic category of exported/imported/ sold good - capital or intermediates, with final goods treated as reference group - and its weight in the firm's total export/import/turnover value. The definition of the latter regressor depends on the explored outcome: when the firm product sale margins are estimated, the regressor will measure the weight of that product in the firm's total production, while it will measure the weight of that product in the firm exports or imports when we investigate the export and import margins at firm-product level. Finally, $\delta_{p}$ represents product fixed effects, while $\epsilon_{f t}$ and $\epsilon_{f p t}$ are firm and firm-product idiosyncratic shocks.

In the following section, the upper panel - panel $A$ - of each table will also show the results from the estimation of models 2 and 3 when the restriction $\beta_{1}=\beta_{2}=0$ is imposed, thus assuming a homogeneous effect of the crisis across firms in order to deliver a first overview of its average impact across firms and firm-product pairs. ${ }^{12}$ In panel B, on the other hand, we let the crisis heterogeneously affect firms and products according to their characteristics.

\section{Results}

Exports and sales. Table 3 shows the evolution and the determinants of export margins at firm and firm-product level. Columns 1-5 display the results for total exports, while columns 6-10 refer to regular exports. Also, in order to compare the evolution of exports and turnover, we report the results for total sales in the last three columns.

From panel A it emerges that, after controlling for firm and product level covariates, the global economic slowdown in 2009 did not reduce either overall or regular exports through the firm extensive margin. Indeed, during the crisis the probability of entry in foreign markets did not significantly change with respect to the previous period and, when total exports are considered, the firm probability to stop exporting in fact decreased. In addition, in line with the existing evidence on the positive association between firm importing and exporting (Kasahara and Lapham, 2008; Muûls and Pisu, 2009; Aristei et al., 2013; Lo Turco and Maggioni, 2013) which may prove more important under the economic downturn (Behrens et al., 2012), from panel B it emerges that importers were actually more likely to start exporting in the recession. The likeliness of the drop of a product from the firm export basket was however increased by the crisis, thus contributing to explain the export slump, even if this result is not confirmed for regular exports. Panel B reveals that the contraction in the overall export scope is mainly concentrated in intermediate goods, especially in firms' marginal product varieties, and is mainly attributable to larger firms. The latter also display a higher probability

\footnotetext{
${ }^{10}$ As previously stated, in this analysis trade products are defined with the 6-digit harmonised GTIP classification, while sold products are still defined with the 10-digit PRODTR classification.

${ }^{11}$ In the analysis of export and import margins we dropped the firm export and import dummies respectively among the explanatory variables.

${ }^{12}$ In order to display the different average firm-product extensive and intensive margins for intermediates and capital goods, product fixed effects are not included in the specifications of panel A. However, their inclusion does not lead to sensitively different results.
} 
Table 3

Extensive and intensive margins of exports.

\begin{tabular}{|c|c|c|c|c|c|c|c|c|c|c|c|c|c|}
\hline & \multicolumn{5}{|c|}{ Total exports } & \multicolumn{5}{|c|}{ Regular exports } & \multicolumn{3}{|l|}{ Sales } \\
\hline & \multicolumn{3}{|c|}{ Extensive margins } & \multicolumn{2}{|c|}{ Intensive margins } & \multicolumn{3}{|c|}{ Extensive margins } & \multicolumn{2}{|c|}{ Intensive margins } & \multirow{2}{*}{$\begin{array}{l}\text { Extensive margins } \\
\text { Drop }^{y}\end{array}$} & \multicolumn{2}{|c|}{ Intensive margins } \\
\hline & Start $^{x}$ & Stop $^{x}$ & Drop $^{x}$ & $\overline{\Delta x_{f}}$ & $\Delta x_{f p}$ & Start $^{x^{\text {reg }}}$ & Sto $p^{p^{\text {reg }}}$ & Dro $p^{x^{\text {reg }}}$ & $\overline{\Delta x_{f}^{r e g}}$ & $\Delta x_{f p}^{r e g}$ & & $\Delta y_{f}$ & $\Delta y_{f p}$ \\
\hline & (1) & $(2)$ & (3) & $(4)$ & (5) & (6) & (7) & $(8)$ & (9) & $(10)$ & (11) & $(12)$ & (13) \\
\hline \multicolumn{14}{|l|}{ Panel A } \\
\hline Crisis & $\begin{array}{l}0.002 \\
{[0.006]}\end{array}$ & $\begin{array}{l}-0.011^{* *} \\
{[0.005]}\end{array}$ & $\begin{array}{l}0.014^{* * *} \\
{[0.005]}\end{array}$ & $\begin{array}{l}-0.167^{* * *} \\
{[0.024]}\end{array}$ & $\begin{array}{l}-0.116^{* * *} \\
{[0.019]}\end{array}$ & $\begin{array}{l}0.003 \\
{[0.004]}\end{array}$ & $\begin{array}{l}-0.011 \\
{[0.007]}\end{array}$ & $\begin{array}{l}-0.01 \\
{[0.008]}\end{array}$ & $\begin{array}{l}-0.070^{* *} \\
{[0.035]}\end{array}$ & $\begin{array}{l}-0.083^{* * *} \\
{[0.031]}\end{array}$ & $\begin{array}{l}-0.022^{* * *} \\
{[0.004]}\end{array}$ & $\begin{array}{l}-0.198^{* * *} \\
{[0.008]}\end{array}$ & $\begin{array}{l}-0.162^{* * *} \\
{[0.012]}\end{array}$ \\
\hline sizet -1 & $\begin{array}{l}0.031^{* * *} \\
{[0.004]}\end{array}$ & $\begin{array}{l}-0.023^{* * *} \\
{[0.002]}\end{array}$ & $\begin{array}{l}-0.031^{* * *} \\
{[0.003]}\end{array}$ & $\begin{array}{l}0.008 \\
{[0.011]}\end{array}$ & $\begin{array}{l}-0.016^{*} \\
{[0.009]}\end{array}$ & $\begin{array}{l}0.011^{* * *} \\
{[0.003]}\end{array}$ & $\begin{array}{l}-0.028^{* * *} \\
{[0.004]}\end{array}$ & $\begin{array}{l}-0.042^{* * *} \\
{[0.004]}\end{array}$ & $\begin{array}{l}-0.01 \\
{[0.015]}\end{array}$ & $\begin{array}{l}-0.028^{* *} \\
{[0.013]}\end{array}$ & $\begin{array}{l}-0.032^{* * *} \\
{[0.002]}\end{array}$ & $\begin{array}{l}0.025^{* * *} \\
{[0.005]}\end{array}$ & $\begin{array}{l}-0.001 \\
{[0.006]}\end{array}$ \\
\hline $\mathrm{lp} t-1$ & $\begin{array}{l}0.015^{* * *} \\
{[0.004]}\end{array}$ & $\begin{array}{l}-0.025^{* * *} \\
{[0.003]}\end{array}$ & $\begin{array}{l}-0.021^{* * *} \\
{[0.004]}\end{array}$ & $\begin{array}{l}-0.001 \\
{[0.016]}\end{array}$ & $\begin{array}{l}-0.007 \\
{[0.011]}\end{array}$ & $\begin{array}{l}0.004 \\
{[0.003]}\end{array}$ & $\begin{array}{l}-0.022^{* * *} \\
{[0.005]}\end{array}$ & $\begin{array}{l}-0.029^{* * * *} \\
{[0.006]}\end{array}$ & $\begin{array}{l}0.019 \\
{[0.024]}\end{array}$ & $\begin{array}{l}0.023 \\
{[0.018]}\end{array}$ & $\begin{array}{l}-0.010^{* * * *} \\
{[0.002]}\end{array}$ & $\begin{array}{l}0.008 \\
{[0.006]}\end{array}$ & $\begin{array}{l}0.009 \\
{[0.008]}\end{array}$ \\
\hline $\exp t-1$ & & & & & & & & & & & $\begin{array}{l}0.008^{*} \\
{[0.004]}\end{array}$ & $\begin{array}{l}0.036^{* * * *} \\
{[0.009]}\end{array}$ & $\begin{array}{l}0.024^{*} \\
{[0.014]}\end{array}$ \\
\hline impt -1 & $\begin{array}{l}0.137^{* * *} \\
{[0.008]}\end{array}$ & $\begin{array}{l}-0.066^{* * *} \\
{[0.008]}\end{array}$ & $\begin{array}{l}-0.073^{* * *} \\
{[0.010]}\end{array}$ & $\begin{array}{l}-0.044 \\
{[0.030]}\end{array}$ & $\begin{array}{l}-0.047^{*} \\
{[0.027]}\end{array}$ & $\begin{array}{l}0.065^{* * *} \\
{[0.005]}\end{array}$ & $\begin{array}{l}-0.094^{* * *} \\
{[0.012]}\end{array}$ & $\begin{array}{l}-0.082^{* * *} \\
{[0.013]}\end{array}$ & $\begin{array}{l}-0.084^{*} \\
{[0.046]}\end{array}$ & $\begin{array}{l}-0.077^{*} \\
{[0.041]}\end{array}$ & $\begin{array}{l}0.008^{*} \\
{[0.005]}\end{array}$ & $\begin{array}{l}0.014 \\
{[0.010]}\end{array}$ & $\begin{array}{l}-0.033^{* *} \\
{[0.014]}\end{array}$ \\
\hline foreignt -1 & $\begin{array}{l}-0.050 \\
{[0.033]}\end{array}$ & $\begin{array}{l}-0.023^{* * *} \\
{[0.007]}\end{array}$ & $\begin{array}{l}-0.025^{*} \\
{[0.013]}\end{array}$ & $\begin{array}{l}-0.055 \\
{[0.039]}\end{array}$ & $\begin{array}{l}-0.022 \\
{[0.033]}\end{array}$ & $\begin{array}{l}0.004 \\
{[0.017]}\end{array}$ & $\begin{array}{l}-0.041^{* * * *} \\
{[0.012]}\end{array}$ & $\begin{array}{l}-0.038^{* *} \\
{[0.016]}\end{array}$ & $\begin{array}{l}-0.076 \\
{[0.058]}\end{array}$ & $\begin{array}{l}0.009 \\
{[0.055]}\end{array}$ & $\begin{array}{l}-0.016^{*} \\
{[0.009]}\end{array}$ & $\begin{array}{l}-0.015 \\
{[0.016]}\end{array}$ & $\begin{array}{l}0.014 \\
{[0.026]}\end{array}$ \\
\hline sharet-1 & & & $\begin{array}{l}-0.490^{* * * *} \\
{[0.007]}\end{array}$ & & $\begin{array}{l}-0.457^{* * *} \\
{[0.021]}\end{array}$ & & & $\begin{array}{l}-0.162^{* * *} \\
{[0.011]}\end{array}$ & & $\begin{array}{l}-0.251^{* * *} \\
{[0.038]}\end{array}$ & $\begin{array}{l}-0.189^{* * * *} \\
{[0.004]}\end{array}$ & & $\begin{array}{l}-0.195^{* * *} \\
{[0.014]}\end{array}$ \\
\hline interm $t-1$ & & & $\begin{array}{l}0.079^{* * * *} \\
{[0.006]}\end{array}$ & & $\begin{array}{l}0.024 \\
{[0.017]}\end{array}$ & & & $\begin{array}{l}0.005 \\
{[0.009]}\end{array}$ & & $\begin{array}{l}0.056^{*} \\
{[0.029]}\end{array}$ & $\begin{array}{l}0.005 \\
{[0.004]}\end{array}$ & & $\begin{array}{l}-0.002 \\
{[0.011]}\end{array}$ \\
\hline capitalt -1 & & & $\begin{array}{l}0.175^{* * *} \\
{[0.008]}\end{array}$ & & $\begin{array}{l}0.01 \\
{[0.024]}\end{array}$ & & & $\begin{array}{l}0.042^{* * *} \\
{[0.014]}\end{array}$ & & $\begin{array}{l}0.051 \\
{[0.047]}\end{array}$ & $\begin{array}{l}0.013^{* *} \\
{[0.007]}\end{array}$ & & $\begin{array}{l}-0.057^{* * *} \\
{[0.017]}\end{array}$ \\
\hline$R^{2}$ & 0.072 & 0.037 & 0.069 & 0.006 & 0.007 & 0.032 & 0.037 & 0.047 & 0.004 & 0.005 & 0.06 & 0.031 & 0.011 \\
\hline Panel B & & & & & & & & & & & & & \\
\hline Crisis & $\begin{array}{l}0.108 \\
{[0.076]}\end{array}$ & $\begin{array}{l}-0.011 \\
{[0.065]}\end{array}$ & $\begin{array}{l}-0.128^{* *} \\
{[0.060]}\end{array}$ & $\begin{array}{l}0.754^{* *} \\
{[0.341]}\end{array}$ & $\begin{array}{l}0.552^{* *} \\
{[0.230]}\end{array}$ & $\begin{array}{l}0.017 \\
{[0.052]}\end{array}$ & $\begin{array}{l}0.07 \\
{[0.096]}\end{array}$ & $\begin{array}{l}0.014 \\
{[0.093]}\end{array}$ & $\begin{array}{l}0.659 \\
{[0.490]}\end{array}$ & $\begin{array}{l}0.963^{* *} \\
{[0.413]}\end{array}$ & $\begin{array}{l}-0.055 \\
{[0.045]}\end{array}$ & $\begin{array}{l}-0.317^{* * *} \\
{[0.117]}\end{array}$ & $\begin{array}{l}-0.075 \\
{[0.157]}\end{array}$ \\
\hline sizet -1 & $\begin{array}{l}0.035^{* * * *} \\
{[0.007]}\end{array}$ & $\begin{array}{l}-0.028^{* * *} \\
{[0.003]}\end{array}$ & $\begin{array}{l}-0.042^{* * *} \\
{[0.004]}\end{array}$ & $\begin{array}{l}0.022 \\
{[0.015]}\end{array}$ & $\begin{array}{l}-0.006 \\
{[0.013]}\end{array}$ & $\begin{array}{l}0.015^{* * *} \\
{[0.004]}\end{array}$ & $\begin{array}{l}-0.033^{* * *} \\
{[0.005]}\end{array}$ & $\begin{array}{l}-0.047^{* * *} \\
{[0.007]}\end{array}$ & $\begin{array}{l}0.004 \\
{[0.022]}\end{array}$ & $\begin{array}{l}-0.034 \\
{[0.022]}\end{array}$ & $\begin{array}{l}-0.028^{* * *} \\
{[0.003]}\end{array}$ & $\begin{array}{l}0.001 \\
{[0.006]}\end{array}$ & $\begin{array}{l}-0.01 \\
{[0.010]}\end{array}$ \\
\hline sizet $-1 \times \mathrm{C}$ & $\begin{array}{l}-0.01 \\
{[0.009]}\end{array}$ & $\begin{array}{l}0.009^{*} \\
{[0.005]}\end{array}$ & $\begin{array}{l}0.011^{* * *} \\
{[0.005]}\end{array}$ & $\begin{array}{l}-0.026 \\
{[0.024]}\end{array}$ & $\begin{array}{l}-0.021 \\
{[0.018]}\end{array}$ & $\begin{array}{l}-0.008 \\
{[0.005]}\end{array}$ & $\begin{array}{l}0.01 \\
{[0.007]}\end{array}$ & $\begin{array}{l}-0.001 \\
{[0.007]}\end{array}$ & $\begin{array}{l}-0.028 \\
{[0.035]}\end{array}$ & $\begin{array}{l}-0.012 \\
{[0.031]}\end{array}$ & $\begin{array}{l}-0.006 \\
{[0.004]}\end{array}$ & $\begin{array}{l}0.043^{* * *} \\
{[0.010]}\end{array}$ & $\begin{array}{l}0.02 \\
{[0.013]}\end{array}$ \\
\hline $\mathrm{lp} t-1$ & $\begin{array}{l}0.019 * * * \\
{[0.006]}\end{array}$ & $\begin{array}{l}-0.022^{* * * *} \\
{[0.005]}\end{array}$ & $\begin{array}{l}-0.031^{* * * *} \\
{[0.005]}\end{array}$ & $\begin{array}{l}0.043^{*} \\
{[0.022]}\end{array}$ & $\begin{array}{l}0.006 \\
{[0.017]}\end{array}$ & $\begin{array}{l}0.003 \\
{[0.004]}\end{array}$ & $\begin{array}{l}-0.016^{* *} \\
{[0.007]}\end{array}$ & $\begin{array}{l}-0.035^{* * *} \\
{[0.009]}\end{array}$ & $\begin{array}{l}0.068^{*} \\
{[0.036]}\end{array}$ & $\begin{array}{l}0.041 \\
{[0.033]}\end{array}$ & $\begin{array}{l}-0.010^{* *} \\
{[0.004]}\end{array}$ & $\begin{array}{l}0.015^{*} \\
{[0.008]}\end{array}$ & $\begin{array}{l}0.01 \\
{[0.013]}\end{array}$ \\
\hline $\mathrm{lp} t-1 \times \mathrm{C}$ & $\begin{array}{l}-0.006 \\
{[0.007]}\end{array}$ & $\begin{array}{l}-0.006 \\
{[0.007]}\end{array}$ & $\begin{array}{l}0.009 \\
{[0.007]}\end{array}$ & $\begin{array}{l}-0.083^{* *} \\
{[0.035]}\end{array}$ & $\begin{array}{l}-0.051^{* *} \\
{[0.024]}\end{array}$ & $\begin{array}{l}0.002 \\
{[0.005]}\end{array}$ & $\begin{array}{l}-0.013 \\
{[0.010]}\end{array}$ & $\begin{array}{l}-0.002 \\
{[0.010]}\end{array}$ & $\begin{array}{l}-0.091^{*} \\
{[0.051]}\end{array}$ & $\begin{array}{l}-0.093^{* *} \\
{[0.042]}\end{array}$ & $\begin{array}{l}0.005 \\
{[0.005]}\end{array}$ & $\begin{array}{l}-0.01 \\
{[0.013]}\end{array}$ & $\begin{array}{l}-0.012 \\
{[0.016]}\end{array}$ \\
\hline $\exp t-1$ & & & & & & & & & & & $\begin{array}{l}-0.008 \\
{[0.006]}\end{array}$ & $\begin{array}{l}0.040^{* * * *} \\
{[0.012]}\end{array}$ & $\begin{array}{l}0.032 \\
{[0.021]}\end{array}$ \\
\hline $\exp t-1 \times \mathrm{C}$ & & & & & & & & & & & $\begin{array}{l}0.014^{*} \\
{[0.008]}\end{array}$ & $\begin{array}{l}-0.007 \\
{[0.019]}\end{array}$ & $\begin{array}{l}-0.009 \\
{[0.029]}\end{array}$ \\
\hline
\end{tabular}




\begin{tabular}{|c|c|c|c|c|c|c|c|c|c|c|c|c|c|}
\hline $\operatorname{imp} t-1$ & $\begin{array}{l}0.114^{* * *} \\
{[0.011]}\end{array}$ & $\begin{array}{l}-0.065^{* * *} \\
{[0.011]}\end{array}$ & $\begin{array}{l}-0.069^{* * *} \\
{[0.012]}\end{array}$ & $\begin{array}{l}0.001 \\
{[0.044]}\end{array}$ & $\begin{array}{l}-0.070^{*} \\
{[0.040]}\end{array}$ & $\begin{array}{l}0.054^{* * *} \\
{[0.007]}\end{array}$ & $\begin{array}{l}-0.092^{* * *} \\
{[0.017]}\end{array}$ & $\begin{array}{l}-0.081^{* * *} \\
{[0.018]}\end{array}$ & $\begin{array}{l}-0.079 \\
{[0.069]}\end{array}$ & $\begin{array}{l}-0.075 \\
{[0.068]}\end{array}$ & $\begin{array}{l}0.002 \\
{[0.007]}\end{array}$ & $\begin{array}{l}-0.007 \\
{[0.013]}\end{array}$ & $\begin{array}{l}-0.051^{* *} \\
{[0.023]}\end{array}$ \\
\hline $\mathrm{impt}-1 \times \mathrm{C}$ & $\begin{array}{l}0.048^{* * *} \\
{[0.016]}\end{array}$ & $\begin{array}{l}-0.003 \\
{[0.015]}\end{array}$ & $\begin{array}{l}-0.005 \\
{[0.014]}\end{array}$ & $\begin{array}{l}-0.085 \\
{[0.067]}\end{array}$ & $\begin{array}{l}0.049 \\
{[0.060]}\end{array}$ & $\begin{array}{l}0.023^{* *} \\
{[0.010]}\end{array}$ & $\begin{array}{l}-0.002 \\
{[0.023]}\end{array}$ & $\begin{array}{l}0.011 \\
{[0.023]}\end{array}$ & $\begin{array}{l}-0.005 \\
{[0.100]}\end{array}$ & $\begin{array}{l}0.034 \\
{[0.096]}\end{array}$ & $\begin{array}{l}-0.005 \\
{[0.009]}\end{array}$ & $\begin{array}{l}0.043^{* *} \\
{[0.021]}\end{array}$ & $\begin{array}{l}0.072^{* *} \\
{[0.032]}\end{array}$ \\
\hline foreignt -1 & $\begin{array}{l}-0.062 \\
{[0.046]}\end{array}$ & $\begin{array}{l}-0.023^{* *} \\
{[0.010]}\end{array}$ & $\begin{array}{l}-0.003 \\
{[0.014]}\end{array}$ & $\begin{array}{l}-0.029 \\
{[0.057]}\end{array}$ & $\begin{array}{l}-0.066 \\
{[0.053]}\end{array}$ & $\begin{array}{l}0.01 \\
{[0.024]}\end{array}$ & $\begin{array}{l}-0.053^{* * *} \\
{[0.017]}\end{array}$ & $\begin{array}{l}-0.008 \\
{[0.025]}\end{array}$ & $\begin{array}{l}-0.150^{*} \\
{[0.091]}\end{array}$ & $\begin{array}{l}0.002 \\
{[0.109]}\end{array}$ & $\begin{array}{l}-0.007 \\
{[0.013]}\end{array}$ & $\begin{array}{l}-0.035^{*} \\
{[0.020]}\end{array}$ & $\begin{array}{l}-0.06 \\
{[0.041]}\end{array}$ \\
\hline foreignt $-1 \times \mathrm{C}$ & $\begin{array}{l}0.02 \\
{[0.060]}\end{array}$ & $\begin{array}{l}0.001 \\
{[0.013]}\end{array}$ & $\begin{array}{l}-0.028^{*} \\
{[0.016]}\end{array}$ & $\begin{array}{l}-0.057 \\
{[0.086]}\end{array}$ & $\begin{array}{l}0.046 \\
{[0.072]}\end{array}$ & $\begin{array}{l}-0.013 \\
{[0.033]}\end{array}$ & $\begin{array}{l}0.025 \\
{[0.023]}\end{array}$ & $\begin{array}{l}-0.013 \\
{[0.026]}\end{array}$ & $\begin{array}{l}0.136 \\
{[0.127]}\end{array}$ & $\begin{array}{l}0.021 \\
{[0.126]}\end{array}$ & $\begin{array}{l}-0.001 \\
{[0.015]}\end{array}$ & $\begin{array}{l}0.042 \\
{[0.034]}\end{array}$ & $\begin{array}{l}0.075 \\
{[0.053]}\end{array}$ \\
\hline sharet-1 & & & $\begin{array}{l}-0.443^{* * *} \\
{[0.009]}\end{array}$ & & $\begin{array}{l}-0.546^{* * * *} \\
{[0.031]}\end{array}$ & & & $\begin{array}{l}-0.134^{* * *} \\
{[0.017]}\end{array}$ & & $\begin{array}{l}-0.409^{* * *} \\
{[0.071]}\end{array}$ & $\begin{array}{l}-0.198^{* * * *} \\
{[0.007]}\end{array}$ & & $\begin{array}{l}-0.272^{* * * *} \\
{[0.024]}\end{array}$ \\
\hline sharet $-1 \times C$ & & & $\begin{array}{l}-0.031^{* * *} \\
{[0.011]}\end{array}$ & & $\begin{array}{l}-0.058 \\
{[0.044]}\end{array}$ & & & $\begin{array}{l}-0.018 \\
{[0.021]}\end{array}$ & & $\begin{array}{l}0.017 \\
{[0.092]}\end{array}$ & $\begin{array}{l}0 \\
{[0.008]}\end{array}$ & & $\begin{array}{l}-0.019 \\
{[0.031]}\end{array}$ \\
\hline interm $t-1 \times C$ & & & $\begin{array}{l}0.020^{* *} \\
{[0.009]}\end{array}$ & & $\begin{array}{l}-0.180^{* * *} \\
{[0.039]}\end{array}$ & & & $\begin{array}{l}0.036^{* *} \\
{[0.016]}\end{array}$ & & $\begin{array}{l}-0.277^{* * *} \\
{[0.071]}\end{array}$ & $\begin{array}{l}0.013^{* *} \\
{[0.007]}\end{array}$ & & $\begin{array}{l}-0.185^{* * *} \\
{[0.025]}\end{array}$ \\
\hline capitalt $-1 \times \mathrm{C}$ & & & $\begin{array}{l}0.008 \\
{[0.011]}\end{array}$ & & $\begin{array}{l}-0.194^{* * *} \\
{[0.058]}\end{array}$ & & & $\begin{array}{l}0.074^{* * *} \\
{[0.026]}\end{array}$ & & $\begin{array}{l}-0.384^{* * *} \\
{[0.116]}\end{array}$ & $\begin{array}{l}0.023^{* * *} \\
{[0.011]}\end{array}$ & & $\begin{array}{l}-0.204^{* * *} \\
{[0.041]}\end{array}$ \\
\hline$R^{2}$ & 0.076 & 0.038 & 0.133 & 0.011 & 0.047 & 0.034 & 0.04 & 0.212 & 0.011 & 0.137 & 0.143 & 0.04 & 0.064 \\
\hline Obs. & 12,788 & 16,617 & 157,525 & 15,618 & 83,649 & 19,339 & 9,874 & 15,192 & 8200 & 11,361 & 58,144 & 29,405 & 50,885 \\
\hline
\end{tabular}

"Significant at $10 \%$ level; ${ }^{* *}$ significant at $5 \%$ level; ${ }^{* * *}$ significant at $1 \%$ level. Robust Standard errors are in brackets. All regressors are one year lags of the variables. " $\times$ C" denotes the interaction of a variable with the Crisis dummy. All estimations for both extensive and intensive margins are obtained by OLS. Regressions in columns 3, 5, 8, 10 in Panel B include 6 digit GTIP product fixed effects, while columns 11 and 13 in Panel B include 10 digit PRODTR product fixed effects. 
to leave the export market in the turmoil, even if the coefficient on the interaction of the crisis dummy and firm size is barely significant and its significance fades away when regular exports are considered. This contrasting finding for regular exports hints at the possibility that the worse performance of larger firms in the overall export intensive margins is mostly driven by their role of carry-alongtraders and by the contraction of their trade intermediary activity. Our data also show slight evidence of a greater resilience of foreign-owned firms in preserving their position in specific product markets abroad.

Intensive margins of exports have been more seriously hit by the crisis than extensive ones. However, comparing the crisis coefficients for total and regular exports in panel A it is evident that the turmoil was much less detrimental for regular exports than for the total ones. Overall export growth decreased by $17 \%$ at firm level (12\% at firm-product level) compared to regular exports which record a fall of $7 \%$ (8\%). CAT activity thus played an important role in shaping the intensive margin response of exports for the Turkish economy. The overall negative shock on the intensive margin, from panel $\mathrm{B}$, seems to originate from the bad performance of more productive firms and heavily involves capital and intermediate goods, especially when regular exports are considered.

After having investigated the evolution of export turnover, the last three columns of Table 3 explore whether overall sales followed the same negative evolution experienced by exports within each firm and product grouping and to which extent the domestic market was able to cushion the shock suffered in foreign markets.

Panel A delivers contrary messages for the extensive and intensive margins of sales. During the crisis, while both firm and firm-product sales growth fell, firms were surprisingly less likely to drop products from their product scope. This finding brings to mind the non-significant average impact of the crisis on the dropping of regular exports and was expected from the above decomposition of sales (see Table 2). Firms may indeed have initiated a process of product diversification in order to cope with the changing foreign scenario. This could reflect the need to redirect sales towards different destination markets located in geographical areas less affected by the crisis and characterised by better growth perspectives (Uygur, 2010). In addition, panel B shows that intermediate and capital goods were less damaged and, turning to firm heterogeneity, larger firms and importers exhibited a greater resilience to the crisis, since they expanded their sales. Comparing this evidence to that on exports from the previous columns, it turns out that domestic sales drove the better performance of large firms and limited the drop in intermediate and capital goods demand. This could hint at the positive impact of some policy interventions on the internal market, such as the temporary consumption tax cuts on durables-usually produced by larger firms-that were implemented by the Turkish government starting from the second quarter of 2009 (Misch and Seymen, 2012). The evidence also shows that exporters more frequently dropped a product from the product mix during the crisis; however, their total sales were no more negatively affected than those of non-exporters. This supports the hypothesis that the crisis has brought about an important churning activity in the product scope of exporters and probably in their destination markets as well.

Imports. Turning to the evidence on imports, from panel A of Table 4 it emerges that imports were hit more seriously than exports at the firm extensive margin. As a matter of fact, in line with our decomposition exercise in Section 2, the crisis reduced the probability to start importing by $1.7 \%$ and increased the probability to stop importing by $1.9 \%$. By the same token, compared to the findings on exports, panel A of the table displays a higher elasticity of the drop probability of import products with respect to the crisis ( $4 \%$ compared to the $1.4 \%$ estimated for exports). At the intensive margin, the reduction in firm and firm-product import growth was also significant and larger than that recorded for exports (26\% and $19 \%$ compared to $17 \%$ and $12 \%$ ).

When the crisis dummy is interacted with the firm level variables in panel B of Table 4, we find that the overall slump in the firm extensive margin is attributable to larger firms and exporters. Under uncertainty, large firms may contract their orders and nevertheless maintain their sales making use of their larger inventory (Alessandria et al., 2010). The result on exporters instead reveals that the adverse foreign demand shock which affected them propagated to their demand for imports. Furthermore, ceteris paribus, more productive firms were less likely to leave the import market in the 
Table 4

Extensive and intensive margins of imports.

\begin{tabular}{|c|c|c|c|c|c|}
\hline & \multicolumn{3}{|c|}{ Extensive margins } & \multicolumn{2}{|c|}{ Intensive margins } \\
\hline & Start $^{m}$ & Stop ${ }^{m}$ & $\operatorname{Drop}^{m}$ & $\triangle m_{f}$ & $\Delta m_{f p}$ \\
\hline & (1) & $(2)$ & (3) & $(4)$ & (5) \\
\hline \multicolumn{6}{|l|}{ Panel A } \\
\hline \multirow[t]{2}{*}{ Crisis } & $-0.017^{* * *}$ & $0.019 * * *$ & $0.043^{* * *}$ & $-0.260^{* * *}$ & $-0.191^{* * * *}$ \\
\hline & {$[0.006]$} & [0.005] & [0.003] & {$[0.026]$} & {$[0.014]$} \\
\hline \multirow[t]{2}{*}{ sizet -1} & $0.050^{* * *}$ & $-0.064^{* * *}$ & $-0.038^{* * *}$ & $-0.024^{* *}$ & $-0.036^{* * *}$ \\
\hline & [0.005] & {$[0.002]$} & {$[0.002]$} & {$[0.010]$} & {$[0.006]$} \\
\hline \multirow[t]{2}{*}{$\operatorname{lp} t-1$} & $0.037^{* * *}$ & $-0.048^{* * *}$ & $-0.044^{* * *}$ & 0.019 & 0.000 \\
\hline & {$[0.004]$} & {$[0.003]$} & [0.003] & {$[0.015]$} & [0.007] \\
\hline \multirow[t]{2}{*}{$\exp t-1$} & $0.138^{* * *}$ & $-0.100^{* * *}$ & $-0.066^{* * *}$ & -0.032 & $-0.104^{* * *}$ \\
\hline & {$[0.008]$} & [0.007] & [0.007] & {$[0.031]$} & {$[0.019]$} \\
\hline \multirow[t]{2}{*}{ foreignt -1} & -0.061 & $-0.021^{* * *}$ & $-0.076^{* * *}$ & -0.028 & -0.002 \\
\hline & {$[0.038]$} & {$[0.007]$} & {$[0.007]$} & {$[0.033]$} & [0.019] \\
\hline \multirow[t]{2}{*}{ rel_sht -1} & & & $-0.345^{* * * *}$ & & $-0.754^{* * * *}$ \\
\hline & & & {$[0.008]$} & & {$[0.022]$} \\
\hline \multirow[t]{2}{*}{ interm $t-1$} & & & $-0.097^{* * *}$ & & $-0.060^{* *}$ \\
\hline & & & {$[0.008]$} & & {$[0.024]$} \\
\hline \multirow[t]{2}{*}{ capitalt -1} & & & $0.088^{* * *}$ & & $-0.109^{* * *}$ \\
\hline & & & {$[0.009]$} & & {$[0.027]$} \\
\hline$R^{2}$ & 0.076 & 0.096 & 0.057 & 0.011 & 0.011 \\
\hline \multicolumn{6}{|l|}{ Panel B } \\
\hline \multirow[t]{2}{*}{ Crisis } & 0.116 & $0.116^{*}$ & 0.049 & 0.399 & $0.371^{*}$ \\
\hline & {$[0.081]$} & {$[0.070]$} & [0.043] & [0.342] & [0.191] \\
\hline \multirow{2}{*}{ sizet -1} & $0.066^{* * *}$ & $-0.068^{* * *}$ & $-0.047^{* * *}$ & $-0.025^{*}$ & $-0.027^{* * *}$ \\
\hline & {$[0.008]$} & [0.003] & {$[0.002]$} & [0.015] & {$[0.008]$} \\
\hline \multirow[t]{2}{*}{ sizet $-1 \times C$} & $-0.026^{* * *}$ & $0.007^{*}$ & 0.002 & 0.006 & $-0.018^{*}$ \\
\hline & [0.010] & [0.004] & {$[0.002]$} & [0.024] & {$[0.011]$} \\
\hline \multirow[t]{2}{*}{$\operatorname{lp} t-1$} & $0.039^{* * *}$ & $-0.037^{* * *}$ & $-0.042^{* * *}$ & $0.053^{* *}$ & 0.007 \\
\hline & [0.006] & [0.005] & {$[0.004]$} & {$[0.021]$} & [0.012] \\
\hline \multirow[t]{2}{*}{$\mathrm{lp} t-1 \times \mathrm{C}$} & -0.004 & $-0.022^{* * *}$ & -0.001 & $-0.067^{* *}$ & $-0.036^{*}$ \\
\hline & [0.008] & {$[0.007]$} & {$[0.004]$} & {$[0.032]$} & [0.019] \\
\hline \multirow[t]{2}{*}{$\exp t-1$} & $0.132 * * *$ & $-0.114^{* * *}$ & $-0.067^{* * *}$ & 0.022 & $-0.063^{* *}$ \\
\hline & {$[0.011]$} & {$[0.010]$} & [0.009] & [0.046] & {$[0.025]$} \\
\hline \multirow[t]{2}{*}{$\exp t-1 \times \mathrm{C}$} & 0.012 & $0.031^{* *}$ & -0.002 & -0.106 & $-0.117^{* * *}$ \\
\hline & [0.015] & [0.014] & {$[0.010]$} & [0.071] & [0.041] \\
\hline \multirow[t]{2}{*}{ foreignt -1} & $-0.102^{* *}$ & -0.012 & $-0.069^{* * *}$ & -0.064 & 0.006 \\
\hline & {$[0.052]$} & [0.009] & {$[0.009]$} & [0.049] & {$[0.028]$} \\
\hline \multirow[t]{2}{*}{ foreignt $-1 \times C$} & 0.074 & -0.016 & -0.011 & 0.069 & -0.041 \\
\hline & [0.067] & [0.011] & [0.008] & [0.075] & [0.038] \\
\hline sharet-1 & & & $-0.278^{* * *}$ & & $-0.865^{* * *}$ \\
\hline & & & {$[0.011]$} & & [0.035] \\
\hline sharet $-1 \times \mathrm{C}$ & & & -0.016 & & $-0.184^{* * *}$ \\
\hline & & & [0.012] & & [0.045] \\
\hline interm $t-1 \times \mathrm{C}$ & & & -0.002 & & 0.043 \\
\hline & & & [0.009] & & [0.047] \\
\hline capitalt $-1 \times \mathrm{C}$ & & & 0.008 & & 0.014 \\
\hline & & & {$[0.010]$} & & [0.056] \\
\hline$R^{2}$ & 0.08 & 0.1 & 0.131 & 0.016 & 0.036 \\
\hline Obs. & 12,067 & 17,338 & 278,717 & 15,954 & 154,210 \\
\hline
\end{tabular}

"Significant at $10 \%$ level; ${ }^{* *}$ significant at $5 \%$ level; ${ }^{* * *}$ significant at $1 \%$ level. Robust Standard errors are in brackets. All regressors are one year lags of the variables. All estimations for both extensive and intensive margins are obtained by OLS. Regressions in columns 3 and 5 in Panel B include 6 digit GTIP product fixed effects

crisis even if their import activity was negatively affected at both the firm and firm-product intensive margin.

It follows that even if more efficient firms did not break their business relationships with foreign suppliers, probably due to the difficulty of finding an input substitute in the domestic market for their high quality production, they reduced the economic importance of their international purchases. 
In line with the inventory explanation, foreign inputs accounting for the highest share in total foreign purchases experienced the lowest growth. The economic destination of the imported goods did not contribute to explaining the evolution of import products either at extensive or intensive margins. The latter result is surprising and could be driven by the very small number of import products in the reference category - consumer goods - which could affect the significance of the shift parameters for intermediate and capital goods.

\section{Summary of the findings and discussion}

The main question we addressed in our work is the role played by firm and product heterogeneity in the Turkish manufacturing response to the crisis. Most of our results fulfil some of the hypotheses outlined and reflect the existing empirical evidence discussed in the introduction. Nevertheless, some important differences have emerged and some new insights may be gathered from the bulk of our evidence. In this section we intend to present an overview of our main findings and to discuss their main implications.

- Firm heterogeneity.

- Size and efficiency. In line with most of the firm level evidence we find that firm size did play a role in shaping the firms' responses to the crisis (Wagner, 2012; Bricongne et al., 2012; Aisen et al., 2012; Behrens et al., 2012). However, our evidence shows that, under the global downturn, large firms significantly contracted the extensive margin of exports only. As discussed in the introduction, although one might expect a better performance of large firms in the crisis, they are more likely to trade those products that are more exposed to the crisis, such as capital and other postponable goods which imply the exploitation of scale economies. Yet larger firms may have a larger export basket and may then importantly adjust their export product scope in order to cope with the adverse external shocks. From another perspective, the lack of any evidence of a more detrimental shock to larger firms' regular exports points to the relevance of their role as trade intermediaries for other manufacturing firms. The drop of some export products may simply reveal indirect exporters' inability to sell their products during the crisis or the worsening of their economic performance. The evidence on more productive firms experiencing a worse performance than less productive ones in the crisis mimics the finding on Belgian firms by Behrens et al. (2012) and reveals that they are responsible for part of the export intensive margin slump. More productive firms tend to export to high income markets (Crinò and Epifani, 2012), which were hit most in the crisis. As a consequence, more efficient firms may have been more affected by the inward shift of high income partners, which implies a reduction of their export sales.

- International exposure of firms. Surprisingly enough, we find no relevant role of foreign ownership in the evolution of trade and turnover in the crisis. This finding is in contrast with evidence provided by Kolasa et al. (2010) and Alfaro and Chen (2012), while it is very close to the work of Behrens et al. (2012). As far as firm access to import markets is concerned we show that importing, as expected, favours export activity in the crisis. Imported inputs may foster export activity thanks to the existence of common sunk costs and/or the enhancement of competitiveness occurring through cost saving or technology transfer (Kasahara and Lapham, 2008; Muûls and Pisu, 2009; Aristei et al., 2013; Lo Turco and Maggioni, 2013). We show that this linkage is strengthened during the crisis. Indeed, the crisis represents a reduction in the flow of expected profits, and if firms sourcing inputs abroad face lower sunk and/or marginal costs compared to non-importers, they may still find exporting a rewarding activity. The positive relationship between importing and exporting in the crisis brings to mind the finding by Behrens et al. (2012); however, the latter study indicates a significant impact of import on the intensive margin, while we find this beneficial effect only for the extensive margin. Finally, we find that, possibly due to the slump in the demand for exports, exporters tend to withdraw from the import market and contract their sales. This result is in line with our expectation of a propagation of the crisis from the export slump to import demand.

- Product heterogeneity. Apart from productivity, further firm characteristics do not appear to have shaped the crisis impact on export growth at the intensive margin. As highlighted by Behrens et al. 
(2012) for the Belgian case, this suggests that supply side factors were possibly secondary compared to the role played by the global demand collapse in the evolution of Turkish manufacturing between 2008 and 2009. In this direction, especially for regular exports, our evidence shows that most of the export growth slowdown in the crisis is absorbed by capital and intermediate goods, recalling the findings on the relevant role of international vertical linkages (Levchenko et al., 2010) which helped the propagation of the fall in the demand for postponable goods. Our evidence corroborates this view for the Turkish economy and is in line with all the existing abovementioned firm level evidence on the 2009 crisis.

Some important and original implications emerge from all this evidence. First, our detailed analysis of extensive margin determinants reveals some important features of the relevance of sunk costs and their asymmetric importance on the supply of exports and the demand for imports. From our findings, we can infer that the exit from foreign destination markets entails the loss of the export sunk costs already borne by the firm. Firms could then work towards defending their market position abroad and avoid facing further burdensome costs in the future. On the contrary, exporters may adjust their export baskets and drop some products, especially if they are marginal varieties and/or originate from intermediary activity. However, as documented by our decompositions above, while the extensive margins played a limited role in the export slump, they emerged as an important driver of the contraction in import demand. On one hand, this may indicate that a relevant restructuring process occurred in Turkish imports with a reduction in the number of importers in total and in each product-market combination. On the other hand, and more likely in our view, it may only reveal that under uncertainty firms hinge more on inventories and less on foreign purchases. All this, however, implies an asymmetry in international buyersupplier relationships where the burden of international tie building seems to be borne by the seller more than the buyer. This interpretation is in line with some recent empirical and theoretical works on the process of export market entry and penetration (Rauch and Watson, 2003; Eaton et al., 2008, 2011b; Arkolakis, 2010). If foreign source and destination markets are characterised by a high degree of competition, it is rather likely that firms may find it harder to acquire new customers than to find new intermediate suppliers. The only exception emerges for high productivity firms whose production is likely to be rather high quality and whose suppliers, as a consequence, could be more difficult to substitute.

Secondly, the role of CAT activity in the Turkish export collapse seems to have been quite important. Regular export flows were not negatively affected at extensive margins and underwent lower contractions at intensive margins compared to CAT flows. Comparing the evidence for regular exports to that on overall exports, it also emerges that larger firms were more likely to drop an export product and leave the export market during the crisis because they stopped or reduced their activity as trade intermediaries. Also, from the comparison of the coefficients on the economic destination of goods, the export collapse of CAT activities seems to be relatively more related to the trading of final goods, while regular exports dropped essentially in intermediate and capital goods. All this calls for a further inspection of the role played by CAT activity in the export collapse of other countries as well.

Finally, what further message can we gather from the specific experience of Turkey in the 2009 crisis? Since our results suggest that the domestic market contributed to cushion the negative shock suffered by Turkish firms in foreign markets, our work provides an interesting implication in times of austerity. As a matter of fact, exporters did not face any reduction in their intensive margins of overall sales during the crisis. Also, larger firms and importers seem to have benefited in particular by domestic demand, actually displaying a better overall sales growth, but there is no significant difference in their exports with respect to smaller firms and non-importers. All this, together with the country's rapid recovery after 2009, could be interpreted as an indirect proof of the positive effect of the fiscal stimulus provided by the Turkish government in the form of a temporary consumption tax cut on durables which was implemented from the second quarter of 2009 (Misch and Seymen, 2012). The Turkish experience therefore provides an important lesson for developing and emerging economies whose development strategies rest heavily on deep integration in the global economy, as it highlights that in order to be resilient in the occurrence 
of a dramatic negative external shock countries need to preserve some scope for an autonomous domestic policy.

\section{Concluding remarks}

The present work contributes to the new and still limited firm level literature on the recent crisis by providing evidence on the response of Turkish manufacturing firms.

The separate analysis of trade margins unveiled the existence of important asymmetries in the reaction of exports and imports to an external shock. As a matter of fact, firm and firm-product level extensive margins had a rather relevant role in shaping the dramatic slump in imports that characterised the Turkish economy in 2009. Also, the investigation of the firm level drivers of such a drop showed that the position of Turkey in the international supply chains may well have played a role: the sudden drop in foreign demand propagated the contraction of the exporters' intermediate purchases abroad and the most affected good categories were intermediate and capital goods.

The analysis of the export evolution also revealed some important findings. First of all, the contraction of foreign sales was counteracted by the extensive margin, which was prominently driven by the firm import activity, which became more relevant when the market size shrank and the competitive pressure became tougher. Secondly, the intensive margin was partially shaped by the performance of more productive firms' sales abroad, possibly due to their focus on the most affected product-market segments. Also, postponable goods were subjected to the largest fall. Finally, but more importantly, our work delivers unprecedented evidence on the evolution of produced and nonproduced exports in the aftermath of the global turmoil. Regular exporters were more resilient than CAT ones. This finding calls, in general, for a more thorough understanding of firm export activity and, in particular, hints at the need to assess to what extent the global trade collapse was driven by the pervasiveness of CAT activity which, in the case of the Turkish and other economies, represents an important fraction of total exports.

Moreover, our investigation suggests that the internal market cushioned the drop in foreign demand for postponable goods: larger firms indeed showed greater resilience in their overall turnover in 2009 compared to the contraction of their export activity. This hints at the effectiveness of the country's temporary fiscal policy measures and at the important role of domestic institutions in curbing a negative foreign demand shock.

In conclusion, the analysis of Turkish manufacturing during the crisis may be considered as a natural experiment that provides the chance to observe if and how firm heterogeneity matters when the economy is under stress. Also, the 2009 contraction of Turkish manufacturing appears to be deeply rooted in the position of this economy in international production networks. Although we show how such supply chains contributed to the spur of the demand downturn from the largest importing countries to the more peripheral suppliers, the observed resilience of larger firms in their domestic sales and the overall quick recovery of the Turkish real sector after 2009 suggest that domestic demand side policies may still play a fundamental role. This should call for a deep reflection on the recent widespread adoption of austerity measures in Europe.

\section{Acknowledgments}

The data used in this work are from Foreign Trada Data, Annual Business Statistics and Production Surveys provided by the Turkish Statistical Office (TurkStat). All elaborations have been conducted at the Microdata Research Centre of TurkStat respecting the law on statistic secrets and personal data protection. The results and opinions expressed in this article are the exclusive responsibility of the authors and by no means represent official statistics. We are grateful to Bülent Tungul, Mahamut Ozgur, Kenan Orhan and Erdal Yildirim from TurkStat for their help with foreign trade data. We also thank Vedat Metin, Ulku Unsal and Oguzhan Turkoglu from the Dissemination Department. Finally, the authors are extremely grateful to the Sabanci University and the jury committee (Professor Izak 
Atiyas, Professor Hasan Ersel, Professor Jeffrey Nugent, Professor Ziya Önis and Professor Dani Rodrik) for having granted this paper the second place at the 2012 Sakip Sabanci International Research Awards.

\section{Appendix A. Data sources}

We make use of three different data sources to build up our sample.

Structural Business Statistics (SBS). The Annual Industry and Service Statistics collect information on firm incomes, input costs, employment, investment activity, the primary 4 digit NACE (rev 1.1) sector of activity and the region of location over the period 2003-2008 which deliver the firm level characteristics used as controls in our estimations. These data cover the whole population of firms with more than 20 employees and a representative sample of firms with less than 20 employees. The economic activities that are included in the survey are those in the NACE sections from C to K and from $\mathrm{M}$ to O. Also, the data cover all firms with more than one local unit regardless of the number of employees and all firms in the following sectors: C, E and I.

Foreign Trade Statistics (FTS). Foreign trade flows at firm level provided by TurkStat are sourced from customs declarations and are available for the 2002-2009 time span. The import and export flows are collected for the universe of the importers and exporters of goods at 12-digit GTIP classification: ${ }^{13}$ the first 8 digits correspond to the $\mathrm{CN}$ classification, and the last 4 digits are national. Additionally, the information on the origin/destination countries of trade flows is available.

Annual Industrial Product Statistics (AIPS). The TurkStat Annual Industrial Product Statistics contain information on the type and number of produced goods, their volume and value of production together with the total quantity and value of total sales from goods produced within the reference year or preceding years. Product data are available for the years 2005-2009 and are collected at 10-digit PRODTR level, ${ }^{14}$ a national product classification with the first 8 digits corresponding to the PRODCOM classification. Production data are available for firms with more than 20 persons employed and whose primary or secondary activity is either in C section (Mining \& Quarrying) or D section (Manufacturing) of NACE Rev 1.1. This database allows us to identify the firm product scope, sales and exports of goods that the firm in fact produces.

\section{Appendix B. Additional tables and figures}

See Tables B1-B3.

Table B1

Variables definition and description.

\begin{tabular}{ll}
\hline$q$ & Description \\
\hline Start ${ }^{x}$ & Extensive margin \\
& $\begin{array}{l}\text { Probability to start exporting measured as a dummy taking value } 1 \text { if the firm exports in } t \text { and } \\
\text { did not export in } t-1\end{array}$ \\
Start ${ }^{\text {reg }}$ & $\begin{array}{l}\text { Probability to start exporting own products measured as a dummy taking value } 1 \text { if the firm } \\
\text { exports own products in } t \text { and did not export in } t-1\end{array}$ \\
Start ${ }^{m}$ & $\begin{array}{l}\text { Probability to start importing measured as a dummy taking value } 1 \text { if the firm imports in } t \\
\text { and did not import in } t-1\end{array}$ \\
Stop ${ }^{x}$ & $\begin{array}{l}\text { Probability to stop exporting measured as a dummy taking value } 1 \text { if the firm stops to export } \\
\text { in } t \text { and exported in } t-1\end{array}$ \\
Sto $p^{x^{\text {reg }}}$ & $\begin{array}{l}\text { Probability to stop exporting own products measured as a dummy taking value } 1 \text { if the firm } \\
\text { stops to export own products in } t \text { and exported own products in } t-1\end{array}$
\end{tabular}

\footnotetext{
${ }^{13}$ This classification undergoes some changes every year and has been harmonised over time following the procedure suggested in Pierce and Schott (2009).

14 The PRODTR classification is the 2006 one, thus it is homogeneous across the years and does not require any harmonisation procedure.
} 
Table B1 (Continued)

\begin{tabular}{|c|c|}
\hline$q$ & Description \\
\hline Stop & $\begin{array}{l}\text { Probability to stop importing measured as a dummy taking value } 1 \text { if the firm stops to import } \\
\text { in } t \text { and imported in } t-1\end{array}$ \\
\hline $\operatorname{Drop}^{x}$ & $\begin{array}{l}\text { Probability to drop an export product measured as a dummy taking value } 1 \text { if the firm drops } \\
\text { the product export in } t \text { and was exporting it in } t-1\end{array}$ \\
\hline Dro $p^{x^{\text {reg }}}$ & $\begin{array}{l}\text { Probability to drop a produced export product measured as a dummy taking value } 1 \text { if the } \\
\text { firm drops the own product export in } t \text { and was exporting it in } t-1\end{array}$ \\
\hline Drop ${ }^{y}$ & $\begin{array}{l}\text { Probability to drop a product from the product mix measured as a dummy taking value } 1 \text { if } \\
\text { the firm drops the product in } t \text { and was producing it in } t-1\end{array}$ \\
\hline Drop $^{m}$ & $\begin{array}{l}\text { Probability to drop an import product measured as a dummy taking value } 1 \text { if the firm drops } \\
\text { the product import in } t \text { and was importing it in } t-1\end{array}$ \\
\hline \multicolumn{2}{|c|}{ Intensive margin } \\
\hline$\Delta x_{f \mid f p}$ & $\begin{array}{l}\text { Annual growth of firm or firm-product level exports measured as the log change in export } \\
\text { sales }\end{array}$ \\
\hline$\Delta x_{f / f p}^{r e g}$ & $\begin{array}{l}\text { Annual growth of firm or firm-product level produced exports measured as the log change in } \\
\text { produced export sales }\end{array}$ \\
\hline$\Delta y_{f \mid f p}$ & Annual growth of firm or firm-product level sales measured as the log change in total sales \\
\hline$\Delta m_{f \mid f p}$ & $\begin{array}{l}\text { Annual growth of firm or firm-product level imports measured as the log change in imported } \\
\text { purchases }\end{array}$ \\
\hline W & Description \\
\hline Crisis/C & Dummy taking value 1 in year 2009 and 0 otherwise \\
\hline size & Firm size measured as the log of the number of employees \\
\hline $\operatorname{lp}$ & Labour productivity measured as the log of real value added per worker \\
\hline $\exp$ & Exporter dummy equal to 1 if the firm exports in that year and 0 otherwise. \\
\hline imp & Importer dummy equal to 1 if the firm imports and 0 otherwise \\
\hline foreign & Foreign ownership dummy equal to 1 if the firm is foreign owned \\
\hline $\mathrm{X}$ & Description \\
\hline interm & $\begin{array}{l}\text { Dummy equal to } 1 \text { if a product is an intermediate good and } 0 \text { otherwise. We define } \\
\text { intermediates those products included in the BEC codes } 111,121,21,22,31,322,42,53\end{array}$ \\
\hline capital & $\begin{array}{l}\text { Dummy equal to } 1 \text { if a product is a capital good and } 0 \text { otherwise, We define capital goods } \\
\text { those products included in the BEC codes } 41 \text { and } 521\end{array}$ \\
\hline share & Share of the product in the total firm output/exports/produced exports/imports \\
\hline
\end{tabular}

\section{Table B2}

Kolmogorow-Smirnov Test on the change of intensive margins between 2009 and 2008.

\begin{tabular}{|c|c|c|c|c|}
\hline & \multicolumn{4}{|c|}{$\begin{array}{l}\text { Firm level margins } \\
2009 / 2008 \text { change in }\end{array}$} \\
\hline & $\Delta x_{f}$ & $\Delta x_{f}^{r e g}$ & $\Delta y_{f}$ & $\Delta m_{f}$ \\
\hline All firms & -0.333 & -0.245 & -0.236 & -0.380 \\
\hline Large firm & -0.404 & -0.282 & -0.202 & -0.413 \\
\hline Small firm & -0.298 & -0.224 & -0.247 & -0.359 \\
\hline$P$-value & 0.000 & 0.008 & 0.000 & 0.000 \\
\hline High productivity & -0.373 & -0.277 & -0.255 & -0.428 \\
\hline Low productivity & -0.280 & -0.199 & -0.227 & -0.300 \\
\hline$P$-value & 0.000 & 0.001 & 0.000 & 0.000 \\
\hline Exporter & - & - & -0.239 & -0.420 \\
\hline Non exporter & - & - & -0.233 & -0.226 \\
\hline$P$-value & - & - & 0.000 & 0.000 \\
\hline Importer & -0.364 & -0.247 & -0.223 & - \\
\hline Non importer & -0.195 & -0.234 & -0.256 & - \\
\hline$P$-value & 0.000 & 0.151 & 0.000 & - \\
\hline
\end{tabular}


Table B2 (Continued)

\begin{tabular}{|c|c|c|c|c|}
\hline & \multicolumn{4}{|c|}{ Firm level margins } \\
\hline & $\overline{\Delta x_{f}}$ & $\Delta x_{f}^{r e g}$ & $\Delta y_{f}$ & $\Delta m_{f}$ \\
\hline Foreign & -0.434 & -0.258 & -0.189 & -0.331 \\
\hline Domestic & -0.326 & -0.244 & -0.238 & -0.384 \\
\hline \multirow[t]{4}{*}{$P$-value } & 0.002 & 0.041 & 0.000 & 0.000 \\
\hline & \multicolumn{4}{|c|}{ Firm-product level margins } \\
\hline & \multicolumn{4}{|c|}{$2009 / 2008$ change in } \\
\hline & $\Delta x_{f p}$ & $\Delta x_{f p}^{r e g}$ & $\Delta y_{f p}$ & $\Delta m_{f p}$ \\
\hline All firms & -0.413 & -0.279 & -0.250 & -0.400 \\
\hline Large firm & -0.448 & -0.274 & -0.225 & -0.431 \\
\hline Small firm & -0.371 & -0.282 & -0.260 & -0.319 \\
\hline$P$-value & 0.074 & 0.035 & 0.000 & 0.000 \\
\hline High productivity & -0.464 & -0.327 & -0.285 & -0.423 \\
\hline Low productivity & -0.338 & -0.216 & -0.218 & -0.366 \\
\hline$P$-value & 0.000 & 0.000 & 0.000 & 0.000 \\
\hline Exporter & - & - & -0.253 & -0.412 \\
\hline Non exporter & - & - & -0.246 & -0.243 \\
\hline$P$-value & - & - & 0.000 & 0.000 \\
\hline Importer & -0.414 & -0.271 & -0.242 & - \\
\hline Non importer & -0.404 & -0.330 & -0.265 & - \\
\hline$P$-value & 0.713 & 0.040 & 0.000 & - \\
\hline Foreign & -0.423 & -0.341 & -0.180 & -0.429 \\
\hline Domestic & -0.411 & -0.273 & -0.253 & -0.389 \\
\hline$P$-value & 0.397 & 0.028 & 0.000 & 0.000 \\
\hline Capital & -0.473 & -0.552 & -0.334 & -0.496 \\
\hline Interm/final & -0.406 & -0.246 & -0.237 & -0.396 \\
\hline$P$-value & 0.000 & 0.002 & 0.000 & 0.000 \\
\hline
\end{tabular}

The equality of distributions of the change in each intensive margin between 2009 and 2008 is tested among different firm and product groups.

Both the values of the change in margins and the $p$-value of the Kolmogorow-Smirnov tests are reported.

As far as the firm size and productivity are concerned, we test the equality of distributions in the change of a given margin between large (with at least 100 employees) and small (with less than 100 employees) firms and between high productive (with productivity above the median) and low productive (with productivity below the median) firms.

\section{Table B3}

Descriptive statistics of the regressors.

\begin{tabular}{lllllr}
\hline Variable & Observations & Mean & S.E. & Min & Max \\
\hline sizet -1 & 30,943 & 3.974 & 0.968 & 2.995 & 9.615 \\
lpt -1 & 29,872 & 9.558 & 0.848 & 2.372 & 14.631 \\
expt -1 & 31,006 & 0.553 & 0.497 & 0 & 1 \\
impt -1 & 31,006 & 0.578 & 0.494 & 0 & 1 \\
foreignt -1 & 30,500 & 0.039 & 0.193 & 0 & 1 \\
\hline
\end{tabular}

The table reports the average (Mean), standard deviation (S.E.), minimum (Min) and maximum (Max) values of the one-year lags of firm variables.

\section{References}

Aisen, A., Álvarez, R., Sagner, A., Turén, J., 2012. Credit contraction and international trade: evidence from chilean exporters. World Development 212-224.

Alessandria, G., Kaboski, J.P., Midrigan, V., 2010. The great trade collapse of 2008-2009: an inventory adjustment? Working Papers 10-18Federal Reserve Bank of Philadelphia. 
Alfaro, L., Chen, M.X., 2012. Surviving the global financial crisis: foreign ownership and establishment performance. Policy Research Working Paper Series 5946The World Bank.

Altomonte, C., Ottaviano, G., 2009. Resilient to the crisis? Global supply chains and trade flows. In: Baldwin, R. (Ed.), The Great Trade Collapse: Causes, Consequences and Prospects. , Ebook, VoxEU.org.

Aristei, D., Castellani, D., Franco, C., 2013. Firms' exporting and importing activities: is there a two-way relationship? Am. Econ. Rev. 149 (1) 55-84.

Arkolakis, C., 2010. Market penetration costs and the new consumers margin in international trade. J. Polit. Econ. 118 (6) $1151-$ 1199 .

Baldwin, R., 2009. The Great Trade Collapse: Causes, Consequences and Prospects Ebook, VoxEU.org.

Barba Navaretti, G., Bugamelli, M., Schivardi, F., Altomonte, C., Horgos, D., Maggioni, D., 2011. The global operations of European firms The second EFIGE policy report, Bruegel.

Behrens, K., Corcos, G., Mion, G., 2012. Trade crisis? What trade crisis. Rev. Econ. Stat..

Bernard, A., Blanchard, E., van Beveren, I., Vandenbussche, H., 2012. Carry-along trade. Working Paper 18246NBER.

Bernard, A., Eaton, J., Jensen, J., Kortum, S., 2003. Plants and productivity in international trade. Am. Econ. Rev. 93, 1268-1290.

Bernard, A., van Beveren, I., Vandenbussche, H., 2011a. Multi-product exporters, carry-along trade and the margins of trade. Working Paper Research 203National Bank of Belgium.

Bernard, A.B., Redding, S., Schott, P.K., 2011. Multi-product firms and trade liberalization. Quart. J. Econ. 126 (3) $1271-1318$.

Bricongne, J.-C., Fontagné, L., Gaulier, G., Taglioni, D., Vicard, V., 2012. Firms and the global crisis: French exports in the turmoil. J. Int. Econ. 87 (1) 134-146.

Chor, D., Manova, K., 2012. Off the cliff and back? Credit conditions and international trade during the global financial crisis. J. Int. Econ. 87 (1) 117-133.

Crinò, R., Epifani, P., 2012. Productivity, quality and export behavior. Econ. J., http://dx.doi.org/10.1111/j.14680297.2012.02529.x.

Eaton, J., Eslava, M., Kugler, M., Tybout, J., 2008. The margins of entry into export markets: evidence from Colombia. In: Helpman, E., Marin, D., Verdier, T. (Eds.), The Organization of Firms in a Global Economy. NBER Chapters. Harvard University Press, pp. $261-338$.

Eaton, J., Kortum, S., Neiman, B., Romalis, J., 2011a. Trade and the global recession. NBER Working Papers 16666National Bureau of Economic Research, Inc..

Eaton, J., Krizan, C.J., Eslava, M., Kugler, M., Tybout, J., 2011b. A search and learning model of export dynamics. Mimeo.

Eckel, C., Neary, P., 2010. Multi-product firms and flexible manufacturing in the global economy. Rev. Econ. Stud. 77 (1) $188-$ 217.

Gabaix, X., 2011. The granular origins of aggregate fluctuations. Econometrica 79 (3) 733-772.

Godart, O., Görg, H., Hanley, A., 2011. Surviving the crisis: Foreign multinationals vs domestic firms in ireland. IZA Discussion Papers 5882Institute for the Study of Labor (IZA).

Goldberg, P.K., Khandelwal, A., Pavcnik, N., Topalova, P., 2010. Multiproduct firms and product turnover in the developing world: evidence from India. Rev. Econ. Stat. 92 (4) 1042-1049.

Greenaway, D., Guariglia, A., Kneller, R., 2007. Financial factors and exporting decisions. J. Int. Econ. 73 (2) 377-395.

Kasahara, H., Lapham, B., 2008. Productivity and the decision to import and export: Theory and evidence. CESifo Working Paper Series 2240CESifo Group, Munich.

Kolasa, M., Rubaszek, M., Taglioni, D., 2010. Firms in the great global recession: the role of foreign ownership and financial dependence. Emerg. Markets Rev. 11 (4) 341-357.

Levchenko, A., Lewis, L., Tesar, L., 2010. The collapse of international trade during the 2008-2009 crisis: In search of the smoking gun. Working Paper 16006NBER.

Lo Turco, A., Maggioni, D., 2012. Imports, exports and the firm product scope: evidence from Turkey. Mimeo Università Politecnica delle Marche.

Lo Turco, A., Maggioni, D., 2013. On the role of imports in enhancing manufacturing exports. World Econ. 36 (1) 93-120.

Manova, K., 2013. Credit constraints, heterogeneous firms and international trade. Rev. Econ. Stud. 80 (2) $711-744$.

Mayer, T., Melitz, M.J., Ottaviano, G.I., 2011. Market size, competition, and the product mix of exporters. NBER Working Papers 16959National Bureau of Economic Research, Inc..

Melitz, M.J., 2003. The impact of trade on intra-industry reallocations and aggregate industry productivity. Econometrica 71 (6) 1695-1725.

Melitz, M.J., Ottaviano, G.I.P., 2008. Market size, trade, and productivity. Rev. Econ. Stud. 75 (1) 295-316.

Misch, F., Seymen, A., 2012. The effects of countercyclical fiscal policy: Firm-level evidence from temporary consumption tax cuts in turkey. Discussion Paper 12-082ZEW.

Mora, J., Powers, W.M., 2009. Did trade credit problems deepen the great trade collapse? In: Baldwin, R. (Ed.), The Great Trade Collapse: Causes, Consequences and Prospects. Ebook, VoxEU.org.

Muûls, M., 2008. Exporters and credit constraints. Working Papers 139National Bank of Belgium.

Muûls, M., Pisu, M., 2009. Imports and exports at the level of the firm: evidence from Belgium. World Econ. 32 (5) $692-734$.

Nocke, V., Yeaple, S., 2006. Globalization and endogenous firm scope. NBER Working Papers 12322National Bureau of Economic Research, Inc..

Paravisini, D., Rappoport, V., Schnabl, P., Wolfenzon, D., 2011. Dissecting the effect of credit supply on trade: Evidence from matched credit-export data. NBER Working Papers 16975National Bureau of Economic Research, Inc..

Pierce, J.R., Schott, P.K., 2009. Concording U.S. harmonized system categories over time NBER Working Papers 14837National Bureau of Economic Research, Inc..

Rauch, J.E., Watson, J., 2003. Starting small in an unfamiliar environment. Int. J. Ind. Org. 21 (7) 1021-1042.

Uygur, E., 2010. The global crisis and the Turkish economy. TWN Econ. Ser. 21 .

Wagner, J., 2012. The microstructure of the great export collapse in german manufacturing industries, 2008/2009. Working Paper Series 233University of Lüneburg.

WTO, 2010. International Trade Statistics. World Trade Organization. 